\title{
Academic Library Salaries in a Seven-State Area
}

\begin{abstract}
To learn more about their educational backgrounds and salaries, the writer undertook a survey of academic librarians in the seven upper plains states of South Dakota, North Dakota, Minnesota, Iowa, Nebraska, Wyoming, and Montana. Results indicate that many administrators hire individuals with preparation below the Masters level yet call them librarians. At the same time those who have two Masters degrees tend to begin at the same or nearly the same salary as those with only the Masters in Library Science. The paper raises questions about the implications of such practices.
\end{abstract}

$\mathbf{I}_{\mathrm{r}}$ IN OUR AFFLUENT society the financial status of librarians is far from encouraging and, at present, there seems to be little basis for optimism about the immediate future. One indication of this dim prospect is that little information is available about existing conditions.

The statistics on college and university libraries compiled by the U.S. Office of Education are helpful, but more detail is needed. Because of disagreement within the profession about the educational requirements necessary for professional service and because some institutions seem to hire persons with low qualifications in hope that they can create instant librarians by the laying on of a title, the profession needs to determine the requisite educational attainments of academic librarians on the operational level. This should include statistics on how many individuals are called "professional" without possessing the Masters degree and also how many have earned degrees in addition to the Masters in library science. Finally, if the

Mr. Massman is Director of Libraries in the University of South Dakota. second Masters is as important as some librarians feel it is, how much are colleges willing to pay for it? And, a related matter, how do librarians' salaries compare with those of faculty members with similar background and experience?

To learn more about prevailing practices with regard to some of the questions raised above, the writer undertook a survey of academic libraries in South Dakota, North Dakota, Minnesota, Iowa, Nebraska, Wyoming, and Montana. The choice of states was based, simply, on geography. Questionnaires were sent to ninety-six libraries in February 1968sixty-eight replied. Of these, twenty-six were public, thirty-seven were private, three did not identify themselves as to type of control, and two more returned the questionnaire without supplying the information sought. The statistics reported in this paper, then, are based on sixty-six replies from the seven states.

Basic to the question of salary and the matter of academic status is the educational qualification expected of professionals. Approximately 12 per cent of all academic librarians in the seven-state area do not have a Masters degree, yet 
they are called librarians. ${ }^{1}$ When the four largest institutions are excluded (the universities of Iowa, Iowa State, Minnesota, and Nebraska-all of which appear to demand the Masters as an essential before the individual may be labeled a librarian), the percentage jumps to more than 25 per cent. This means that more than one of every four librarians in the responding institutions (the big four excepted) has the name without the usual education-if indeed the Masters degree is the basic requirement for entrance into the profession. Looking at the results in another way, twenty-nine of the sixty-six responding libraries, or nearly 44 per cent, employ individuals without the degree but call them librarians. This practice prevails in almost all types of academic libraries, both public and private, from the smallest to some of those which serve 6,000 to 7,000 students. The four largest libraries are the only exclusion. ${ }^{2}$

One might raise the question of whether current practice in some institutions has implications as far as the status of librarians is concerned. If the $\mathrm{PhD}$ is the accepted level of preparation for the faculty, how do they react to the profession of librarianship which accepts people as being fully qualified with only the Bachelors degree? Someone who has an undergraduate degree and no library science, or perhaps fifteen or twenty undergraduate credits in this area, can hardly be held up as an example of erudition to a faculty member who may well have had as many credits in one subfield of his own discipline.

Nearly 35 per cent of the respondents

\footnotetext{
1 The older fifth year BS in LS is considered, for the purposes of this paper, the equivalent of the Masters.

2 The questionnaire needs refinement at this point. No doubt a few individuals who are listed as librarians have a specialty in a related area such as computer science or in another discipline. Nevertheless, the conclusion that many individuals in academic institutions are called librarians even though they do not have any appropriate Masters degree is, in general, an accurate assessment of existing conditions.
}

reported that they were sometimes forced to hire individuals who did not meet their expectations-although one librarian replied that he would be happy to be forced to hire anyone, whether qualified or not. The question obviously arises, is hiring someone just for the sake of filling a position a boon either to the profession or to that library? Chairmen of academic departments have been known to hire men without appropriate qualifications as temporary expediencies for the sake of getting someone who can walk into the classroom on the first day of the new term. More energetic, aggressive, and successful chairmen let it be known, however, that they are only "making do," and insist that they need more money to get better men next year. Most institutions, of course, deny tenure to anyone who does not have the $\mathrm{PhD}$. This puts additional pressure on the administration to provide more money.

Librarians have dealt in the currency of dedication to service for a long time, and some will feel that it is time to begin dealing in hard cash. A large portion of the problem, of course, is that if the librarian gets a small sum of money and hires whomever he can get, calling that person a librarian, why should the central administration provide more money next time? The library found someone it called a librarian for $\$ 5,000$ last year. Why should a librarian cost $\$ 9,000$ or $\$ 10,000$ this year? Some library administrators have been effective in this area, but until more of them change their tactics it is likely that average salaries for librarians will remain low. The professional associations also have a mission in this area. Getting salaries up to a competitive level might go far toward solving the shortage of librarians.

Some library administrators are obviously "making do" with what they can get rather than demanding what they 
need. Do department chairmen in chemistry or history or music hire teachers with degrees in biology or English or theater? Some can rightly claim that a subject degree in another discipline is valid preparation for some kinds of librarianship, but library science itself is also a discipline worthy of study. If there are inadequacies in the curriculum, as some claim, the only solution is to work to improve it. In general, however, library science courses at most graduate schools probably compare favorably with Masters level courses in other disciplines.

This, however, leads to another question. If subject knowledge is important, how well do academic libraries pay for it? Nearly 15 per cent of all librarians in the survey have at least two Masters degrees. This is larger than the percentage of those who do not have the Masters in library science.

The individuals with two Masters degrees are employed in thirty-one of the sixty-six reporting libraries, or nearly 47 per cent, yet fewer than one in every four libraries (sixteen of the sixty-six, or 24.2 per cent) say that they will automatically pay for the extra academic preparation-even though some professionals seem to consider the second Masters more significant than the $\mathrm{PhD}$ in library science. Of those which give extra compensation the usual range is $\$ 200$ to $\$ 500$ with the weighting on the lower end of that scale. Only one institution approaches a realistic figure-up to $\$ 1,000 .^{3}$

If librarians consider the second Masters degree significant, they should doubtless work harder toward the development of salary increments attractive enough to encourage people to invest the

\footnotetext{
${ }^{3}$ Especially in the larger institutions, the person with the second Masters may be brought in at the beginning salary, but the additional degree will make it possible for him to advance more quickly. Consequently, over a period of time the additional education may result in a higher salary.
}

necessary time and energy to earn the extra degrees. How much does it cost to attend a university to earn a second Masters? Estimates will vary depending on the institution and the degree, but an automatic increment of at least $\$ 1,000$ per year would seem to be an absolute minimum as an inducement to encourage further education, and this should be built into the schedule. Until encouragement is given through the pay check, other arguments for it sound hollow. With librarians as with faculty members or automobiles, the extras cost money, and the sooner the profession recognizes this the better. At present the individual in the library profession with the extras is more often than not treated like the standard model.

To become more specific about the matter of money, more than half (thirty-four of sixty-six respondents, or 51.5 per cent) of the institutions reported that salaries for librarians were equal to those of faculty members with equivalent background and experience; yet when librarians' salaries are compared with American Association of University Professors (AAUP) reports, the case appears to be somewhat different.

Evidently some librarians are not familiar with faculty salaries at their institutions. An illustration will demonstrate this point. Twelve respondents from public colleges and universities identified themselves and reported equal salaries for librarians and faculty members. Instructors at three of the institutions fell into the AAUP's " $\mathrm{B}$ " compensation scale for the 1967-68 term which shows a minimum salary of $\$ 6,100$ and an average of $\$ 7,300$ for nine months. ${ }^{4}$

\footnotetext{
4 "On the Financial Prospects for Higher Education: the Annual Report on the Economic Status of the Profession, 1967-68," AAUP Bulletin, LIV (June 1968), 197, 208-36. All subsequent references to the AAUP report on salaries will be found on these pages.

The AAUP's averages for total compensation have been adjusted when applied to librarians, and only the salaries of beginning librarians were used for purposes of comparison.
} 
At two of these three institutions, beginning librarians are near the average scale; at the third institution, however, the salary of beginning librarians is well below that of the minimum level for instructors at the same institution.

Instructors at seven of the twelve institutions mentioned above fall into the AAUP's "A" compensation scale which shows a minimum rate of $\$ 6,600$ and an average of $\$ 7,930$. At four of these seven the salary of beginning librarians meets the minimum level for instructors, but at only one institution does it approach the average. Again, at three institutions the salary for beginning librarians falls well below the minimum beginning salary for instructors at class " $\mathrm{A}$ " institutions, and at one of these it even falls below the minimum for class "B" institutions.

What can one conclude from this? Assuming that the writer has made no gross errors in interpretation, one can only suggest that librarians do not receive equal pay for equal preparation; and, further, that some head librarians do not know what faculty members earn. In those institutions in which librarians are on the same salary scale as their teaching colleagues, the librarians definitely tend to be at the bottom of the scale-if not below ground level. In many cases the librarian works for twelve months for approximately the same sum as instructors earn in nine months.

If librarians are to compete for talent in the open market, comparisons must also be made on a broader scale. Few librarians have a background in the sciences, and it is not hard to see why. In 1967-68 the average beginning salaries for men with the Bachelors degree in chemistry, mathematics, or physics was $\$ 766$ per month, or $\$ 9,192$ per year. For men with the Masters degree in these disciplines, but without experience, the average beginning salary was more than $\$ 100$ per month higher than that for candidates with the Bachelors. This amounts to an "automatic" increase of more than $\$ 1,200$ for the additional education. Of even greater significance, however, is the fact that the average beginning salary for men with the Bachelors degree in nontechnical fields (the humanities, social sciences, and business) was $\$ 693$ per month, or $\$ 8,316$ per annum. ${ }^{5}$

How does this compare with librarians? In those public institutions which reported that librarians' salaries were equal to faculty salaries with similar backgrounds, the average for beginning librarians without experience was $\$ 7,933$ for twelve months. In the remaining public institutions salaries averaged $\$ 7,234$. For private colleges which reported librarians' salaries equal to faculty members', the average beginning librarian's salary was $\$ 6,784$; those which reported unequal salaries averaged only slightly lower at $\$ 6,735$, a difference of but $\$ 49$. The average beginning salary for librarians in all institutions combined was $\$ 7,159$, which is $\$ 146$ below the $\$ 7,305$ salary reported in 1967 for beginning librarians throughout the country. ${ }^{6}$ If, however, only the public institutions are considered, the average is $\$ 7,618$, which is somewhat higher than the national average.

Far more significant than the average, however, is the salary range for beginning librarians. For private institutions the range in 1967-68 was a low of $\$ 5,000$ and a high of $\$ 9,333$. The reporter at the low end of the scale stated that this was for a candidate with the Bachelors degree although the individual appears to have been hired as a fully qualified librarian. For public institutions the range was $\$ 6,000$ to $\$ 10,133$. In both cases salaries were computed on a twelve-month basis.

\footnotetext{
5 "Salary Survey: A Study of 1967-68 Beginning Offers, Final Report, June 1968" (Bethlehem, Penn.: The College Placement Bureau, 1968), p. 5-6.

'Carlyle J. Frarey and Richard S. Rosenstein, "Placements and Salaries in 1967," Library Journal, XCIII (June 15, 1968), 2447.
} 


\section{SALARY SURveY}

Name of institution (optional) If you do not wish to identify your institution, please indicate the type of school. Private ..... State ..... College ........ University .....

1) Number of librarians with a Masters degree in Library Science ......

2) Number of librarians with the older BS in Library Science rather than the Masters .......

3) Number of librarians you consider professionals who do not have a degree in Library Science .......

4) Number of librarians with a second Masters degree ......

5) Number of librarians with work beyond the Masters degree .......

6) Number of librarians with the Ph.D. degree in Library Science .......

7) Number of librarians with the Ed.D. or Ph.D. degree in other subject areas .......

8) Do you have a salary schedule giving regular annual increments? ..... If so, what is the usual annual increment? ......

9 ) Do you use a merit system in determining salary increases? ..... If so, what was last year's range of increases ?...... to ......

10) Salary of beginning librarians without experience ......

11) How much of an increment do you give to candidates without experience if they have special qualifications, outstanding academic records, or superior recommendations? .......

12) Do you automatically make special adjustments for additional education such as a second Masters degree? ...... If so, how much for a second Masters degree? .......

13) When you add a new staff position, do you ordinarily get a specific sum of money or do you get a salary range so you can negotiate with applicants? A specific sum? ...... A salary range? ..... If you get a salary range, what is the usual range for beginning positions? ...... For administrative heads?

14) Are salaries for librarians equal to salaries of faculty members with similar educational background and experience? Yes ..... No ..... If not, approximately how much higher ...... or lower ..... are salaries of librarians?

15) Are you sometimes forced to hire librarians who fail to meet your expectations because you are unable to find qualified candidates? Yes ...... No ...... If yes, why are you unable to attract qualified candidates? ......

16) Additional comments.

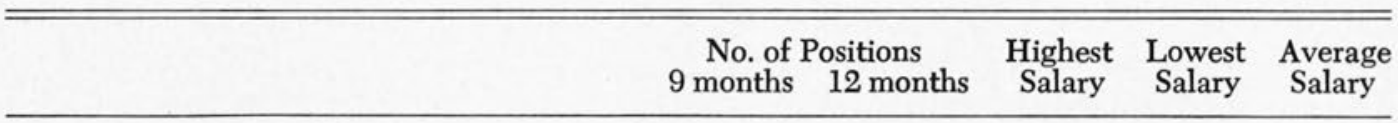

Chief Librarian

Associate or Assistant Librarian

Branch Librarians

Department Heads

All other Librarians 


\section{Conclusion}

Because no terms were defined and because no instructions accompanied the questionnaire, the respondents had to interpret each item on the basis of personal experience and local conditions. It is for this reason, too, that many of the items on the questionnaire will not be discussed in this paper. One respondent, for example, gave a minimum beginning salary of $\$ 6,500$ but then reported an average salary of $\$ 4,300$ for all other librarians (i.e., librarians other than the director, assistant directors, branch librarians, and department heads). A more detailed and more carefully administered questionnaire seeking information along the lines of this study could produce more accurate information which should be of considerable value to library administrators.

In spite of the shortcomings of the questionnaire, however, it appears that considerable inequities exist between salaries of librarians and those of faculty members with similar qualifications and experience. The only reason for optimism about the future is the fact that at least two institutions offer $\$ 10,000$ or more per annum to beginning librarians. The writer is convinced that the current practice in various institutions of hiring anyone who can be pressed into service or who is willing to accept a job at a low salary is a disservice, over the long run, both to the institution and to the profession. Such action does not put pressure on the administration to provide additional funds nor does it enhance the status of the profession. These facts prompt one to ask if it would not be appropriate for professional associations to establish minimum qualifications for admission to the ranks of librarians and also officially to encourage education beyond the minimum professional level? It might also be appropriate to ask if the professional associations should develop salary objectives such as those of the AAUP?

TABLE 1

Salaries of Beginning Librarians

\begin{tabular}{|c|c|c|c|}
\hline & & $\begin{array}{c}\text { Private } \\
\text { Institutions }\end{array}$ & $\begin{array}{l}\text { Public } \\
\text { Institutions }\end{array}$ \\
\hline $\begin{array}{l}\text { Average } \\
\text { Low salaries } \\
\text { High salaries }\end{array}$ & $: \quad:$ & $\begin{array}{r}6,780 \\
. \quad 5,000 \\
. \quad 9,333\end{array}$ & $\begin{array}{r}7,618 \\
6,000 \\
10,133\end{array}$ \\
\hline
\end{tabular}

All salaries are computed on a twelve-month basis.

TABLE 2

EDUCATION OF LibRARIANS

\begin{tabular}{|c|c|c|}
\hline & $\begin{array}{l}\text { Per Cent of } \\
\text { Librarians }\end{array}$ & $\begin{array}{l}\text { Per Cent of } \\
\text { Employing } \\
\text { Institutions }\end{array}$ \\
\hline $\begin{array}{l}\text { Without Masters in } \\
\text { library science } \\
\text { With second }\end{array}$ & . $25.2^{\circ}$ & 43.9 \\
\hline $\begin{array}{l}\text { Masters degree } \\
\text { With work beyond } \\
\text { the Masters in }\end{array}$ & . $\quad 14.7$ & 47 \\
\hline $\begin{array}{l}\text { library science } \\
\text { With the Ph.D. or }\end{array}$ & . 14.1 & 43.8 \\
\hline Ed.D. degree & .2 & .8 \\
\hline
\end{tabular}

